\title{
POST-ELECTION SOUTH AFRICA \\ The Continuing Case for Electoral Reform
}

\author{
By \\ Roger Southall
}

Roger Southall is Distinguished Research Fellow, Democracy and Governance at the Human Sciences Research Council

Private Bag X41, Pretoria, 0001, South Africa

Tel: +27(0)12 302.2809; Fax: +27(0)12 302.2801

e-mail: RSouthall@hsrc.ac.za

\begin{abstract}
In May 2002, the South African government appointed an Electoral Task Team (ETT), headed by Dr Frederick Van Zyl Slabbert and composed of a mix of academics, lawyers, electoral specialists and senior officials of the Independent Electoral Commission (IEC), to consider the case for reform of the country's proportional representation (PR) electoral system. The latter had provided the framework for the highly successful conduct of South Africa's first two democratic elections in 1994 and 1999, yet the country's final Constitution (promulgated in 1996) had dictated that the electoral system should be reviewed, with the proviso that any change would result 'in general' in proportional representation. In the event, the ETT submitted a majority report that recommended adoption of a Mixed Member Proportional Representation system (MMP) (although the report did not call it that) and a minority report that favoured retention of the existing national list system of PR. The government responded by accepting the recommendation of the minority report, ensuring that the 2004 general election would be conducted along exactly the same lines as the two previous elections, although recommending that further consideration be given by the new Parliament to electoral system change. Consequently, now that the African National Congress (ANC) has been returned to power with an increased, and overwhelming, majority it is appropriate not only to consider anew the case for electoral reform but to assess the political dynamics which would appear to determine its likelihood.
\end{abstract}

\section{The ANC's Rejection of Electoral Reform}

South Africa presently votes according to a PR system which features a pure list system of one national list (for 200 seats in a 400-seat National Assembly) and nine provincial lists (for another 200, the length of provincial lists varying according to population size of the nine individual provinces) with no minimum threshold for 
parties to gain representation beyond the vote required to win one seat. ${ }^{1}$ There is no doubt that this system, overall, has served South Africa remarkably well. It was adopted during the negotiation process which preceded the transition to democracy in order to ensure maximum representivity of opinion within Parliament, and has served to ensure that all minority parties that enjoy a reasonable level of support have secured representation: seven parties gained representation in the National Assembly of 1994, twelve in that of 1999 and twelve in that of 2004, these parties ranging widely across the racial and ideological spectrum. Within this context, of course, the ANC's proportion of the vote has grown from 62,65 per cent (252 seats) in 1994 to 66,36 per cent (266 seats) in 1999 to 69,68 per cent (279 seats) in 2004 , this reflecting not merely its overwhelming popularity among the electorate but the fragmentation and relative lack of appeal of the parties of opposition. However, although the ANC's predominance is unchallenged, the outcome of its growing dominance of Parliament has led to widespread argument that it has become a 'dominant party'. Guaranteed recurrent victories at the polls, its dominance has translated into behaviour that undermines the spirit and practice of democracy via, inter alia, the steamrolling of minority opinion in Parliament, the use of the majority in Parliament to deny appropriate scrutiny of the affairs of government; the effective construction of a 'party-state' by the 'deployment' of party loyalists to positions of state, and the effective de-legitimisation of opposition (and most notably of the Democratic Alliance, the official opposition, which is regularly depicted as serving the reactionary interests of only white South Africans) ${ }^{2}$. Now, whether or not the full implications of this categorisation of the ANC as a 'dominant party' are accepted, it is evidence that co-existent with majority support for the ANC there is widespread popular concern that Parliament as a whole, and individual members of Parliament (MPs), are inadequately accountable to the electorate.

It was precisely this concern that led to the Majority Report of the ETT, which argued for the adoption of 69 multi-member constituencies electing $300 \mathrm{MPs}$, who would be topped up by $100 \mathrm{MPs}$ elected by national list PR. This recommendation had been made because, while accepting the need for and the popularity and representivity of the past electoral outcomes provided by $\mathrm{PR}$, the majority of the ETT also accepted that there was a widespread demand not only for MPs to be accountable but to represent particular geographic areas. In part, this flowed from widespread memories of the constituency system as it had operated before 1994. To be sure, racially restricted and defined electorates had predetermined

1 The same system, suitably adjusted, operates in the nine provincial elections, which have hitherto been conducted simultaneously with the national election. The discussion about reform which follows applies as much to the provincial level as to the national level, but for reasons of clarity and simplicity the article will refer only to the national system.

2 Arguments about whether the ANC is a 'dominant party' continue to reverberate and, although they are more often associated with the criticism that comes from the DA (and associated academics), they also emanate from the Left. The issue was central to the debate about the role of opposition parties published after the general election of 1999 (Southall 2001). 
undemocratic outcomes, whether elections - all conducted via the plurality or firstpast-the-post system - had been for the whites-only National Assembly, the Indian and coloured chambers of the tripartite Parliament introduced from 1984, elections for the numerous Bantustan parliaments, or even (going further much further back in history) for the three (white) Native Representatives who, between 1936 and 1959, sat in Parliament on behalf of qualified African male voters from the Cape. Nonetheless, for all the obvious flaws of the pre-1994 electoral systems, they had offered a direct connection, via geographic constituencies, between the voters and individual representatives which was broken with the adoption of the PR system in 1994, and there are indications that the loss has been sorely felt. (In this regard, it is worth recalling that racially restricted franchises meant that the electorates for constituencies, for whatever the fora, were relatively small, allowing for fairly close connections between representatives and voters; a proximity which was probably enhanced by the rural nature of much of South African society, not least in the sense that it facilitated the survival of small town, face-to-face election campaigning until the very end of apartheid). Hence it was that the hankering after a closer relationship between voters and MPs was demonstrated by the survey commissioned by the ETT to examine popular attitudes towards the existent electoral system (Southall and Mattes 2002; Mattes and Southall 2004).

Because respondents were unlikely to have detailed knowledge of the differences between alternative electoral systems, the questions posed about electoral system preference in the survey were necessarily indirect. Nonetheless, the responses received were highly informative. Seventy-two per cent of respondents felt that the post-1994 national list PR electoral system was 'fair to all parties' and 81 per cent felt that it included 'many voices in Parliament', even though, almost inevitably in South Africa's racially segmented society, there was a marked tendency for blacks to be happier about the virtues of the system than whites. Nonetheless, for all this relatively high level of satisfaction about the representivity and fairness of the system there was simultaneously a strong undercurrent of concern about the extent to which it provided for accountability. Certainly, 68 per cent of respondents answered positively the question 'Does the voting system help voters hold the parties accountable for their actions?' but only 60 per cent answered positively a follow-up question which asked: 'Does the voting system help voters hold individual representatives of government accountable for their actions.' Meanwhile, the survey also gave a strong indication that South Africans want an electoral system that enables them to select their legislators more directly than is allowed for by the party list system, and to have more direct access to legislators so that they can better represent their interests and opinions. Hence, for instance, 71 per cent said they wanted to vote for a candidate from the area in which they lived (43 per cent feeling that local candidates would represent people's opinions or interests more adequately, 23 per cent recording answers which focused on issues of proximity, fairness and trust, and 22 per cent highlighting issues of constituency service). 
Alongside such views there were other answers which indicated that a majority of respondents (51 per cent) agreed that elected representatives should be free to criticise their own political parties, while 47 per cent stated that MPs should be able to vote according to their own beliefs (rather than always having to follow their party's line) (Mattes and Southall 2004, pp 58-65). As the individual autonomy of representatives tends to be strongly enhanced by their being elected from geographic (especially single-member) constituencies, these views amongst respondents were further indications that respondents to the survey wanted to combine the national list system's advantages of representivity with adjustments to it which would strengthen the bonds between voters and individual MPs. In conclusion, as was noted at the time, South Africans were generally satisfied with the electoral system, yet significantly higher proportions were dissatisfied than was desirable. Meanwhile, South Africans also emphasised other values - such as the virtues of independent-minded legislators accountable to grass-roots opinionthat the national list system of PR had difficulty in producing. Finally, reference was made to findings of the July-August 2000 Afrobarometer survey, which indicated that the two Southern African countries with PR systems (South Africa and Namibia) also had the lowest levels of citizen contact with national legislators (a mere 1 per cent compared with a range of between 5 and 8 per cent of voters in most other countries in Southern Africa). It was concluded that, while the introduction of some form of constituency system would not be sufficient to enhance politicians' accountability, it was manifestly a desirable step which would provide citizens with some sense of ownership of their representatives in Parliament.

To be sure, there were some strong objections to any introduction of constituencies from a gender lobby, which argued that this would lead to a reduction in the number of women in Parliament (eg, Morna 2002). This was easily rebutted by two responses. The first was that even if women were to find difficulty in securing nominations to represent parties at constituency level, parties could compensate by packing their PR lists with women to ensure an adequate female legislative presence. Second, and more convincing, was the argument that - as demonstrated by the ANC's decision to place sufficient women on its national list to ensure a 30 per cent presence of women in Parliament - the key factor in guaranteeing the election of female MPs lies in parties' commitment to gender equality far more than it does in the nature of the particular electoral system chosen. In other words, if parties want to secure the election of women they can find a way of doing so.

A second set of objections to the introduction of MMP for the 2004 elections revolved around practicability. What is notable in this regard is that the issue of demarcation of constituencies should not have been a problem, for the 69 constituencies (which would have between three and seven members) recommended by the ETT majority had already been identified and demarcated geographically and electronically by Mr. Norman Du Plessis of the Independent Electoral Commission (IEC) on the basis of the IEC's own list of registered voters within already delineated municipal boundaries (with appropriate variations in 
size and the number of MPs being allowed for by reference to geography, density of population, sense of community, and so on). Furthermore, because the IEC already operated on the basis of neighbourhood voters' rolls, the introduction of constituencies would not require any major reconception of the computer based electoral list (for a recent discussion, see Amato 2004).

More convincing, perhaps, was the argument that if a change to the electoral system in favour of MMP was introduced the IEC would have to undertake a massive campaign to educate voters about the mechanics of the new system. Nonetheless, even if this was a serious issue, this objection failed to take into account that the move from a constituency based to a MMP system had been achieved remarkably swiftly and successfully in neighbouring Lesotho for that country's 2000 general election. This example was heralded publicly before the ETT at an open workshop to discuss electoral alternatives (Matlosa 2003), with the key factor in this regard being that voters had adapted to the new system readily, with remarkably little confusion (Fox and Southall 2003). Any suggestion that the mass of voters would be incapable of understanding a new system must therefore be deemed patronising. Overall, it is difficult to escape the conclusion that the MMP recommendation contained in the majority report of the ETT was rejected out of the ANC's sense of self-interest.

The national list PR system had clearly served the ANC's interests well in returning successive proportional majorities. Yet why would there have been an objection to the introduction of MMP, whose proportional list mechanism would have compensated for any lack of proportionality introduced by constituencies? The ANC's public answer was indicated by its submission to the ETT, which was approved by its National Policy Conference in 2002. In the submission, whilst conceding that a mixed system would provide for overall proportionality, the party argued that smaller parties would be unlikely to win constituencies (and hence would be divisive), while, because the ANC would be likely to win the large majority of constituencies, it would have fewer PR seats to distribute and hence would find it difficult to achieve overall representivity amongst its MPs (ANC 2002). The ANC therefore preferred to stay with the present PR system, onto which it has informally grafted a constituency system whereby it has allocated individual MPs to take responsibility for particular geographical areas.

While these issues are certainly real ones, which do require debate, the more likely reason why the ANC chose to reject reform would seem to lie in a reluctance of the senior party hierarchy to reduce its ability to manipulate who is elected to Parliament. At present, the ANC requires its structures, from branch up to provincial levels, to select and rank their candidates in what are, in effect, primary elections. This, commendably, is done openly, but subsequently, the ANC at national level takes it upon itself to confirm, and if need be, adjust such nominations and rankings. In part, this allows the party to ensure that its lists offer female and (racial) minority candidates in appropriate proportions. Yet, importantly, it also confirms centralised authority, serving as a bulwark against party division and factionalism; such central 
control a counterpart to the President's retention of the right to appoint premiers over the heads of provincial structures, whose preferences - expressed in terms of election of provincial ANC chairpersons - have, in quite a number of cases, been deliberately ignored. The rejection of constituencies would appear to follow the same logic: the party at national level, acutely conscious of the factionalism that has bedevilled a number of provincial party structures (notably in the Free State and Eastern Cape), appears determined to prevent the introduction of constituencies, selection of candidates for which would require intra-party competition between individual aspirant candidates. Such local battles could well encourage local factionalism while simultaneously providing individual MPs with a demarcated geographical base which could render them less dependent upon the goodwill of the party at national level.

This interpretation is strengthened by the recent allegations made by Frederick van Zyl Slabbert that the ANC had appointed the ETT merely because it was compelled to do so by the Constitution, and that it had never had any intention of implementing any recommendations for a change in the electoral system (Sunday Independent 3 October 2004). It is also supported by the strong suspicion that the minority of the ETT members who favoured retention of the national list PR system were swayed principally by their loyalty to the ANC.

\section{The Continuing, Aggravated Case for Electoral Reform}

The case for South Africa to move to a form of MMP is now stronger than it was before the 2004 election. This is indicated, firstly, by further evidence that the voting public would welcome an adjustment of the system to provide for a greater sense of ownership of MPs, and secondly by the reaction both to the latest bout of floor crossing and to what the media has called the 'Travelgate' scandal.

In the lead-up to the recent election, the Democracy and Governance research programme of the Human Sciences Research Council collaborated with the Sociology of Work Unit of the University of the Witwatersrand in a survey of the political attitudes of some 650 members of the Congress of South African Trade Unions (Cosatu). As with surveys undertaken prior to the 1994 and 1999 elections, this one was conducted in the principal centres of industrial activity (Gauteng, Durban, Port Elizabeth/East London and Cape Town) and across diverse sectors of the economy. ${ }^{3}$ Overall, there were four sets of answers that relate, directly, or indirectly, to the issue of electoral reform.

First, and particularly significant for our purposes, is that the results of the survey indicated that Cosatu workers remain at the core of ANC support; fully 73 per cent (compared to 75 per cent in both previous surveys) indicated that they

3 The findings are to be published by the HSRC in a collection to be edited by Sakhela Buhlungu of the University of the Witwatersrand. 
intended to vote for the ANC. This compares with an election result that saw 70 per cent of the electorate voting for the ANC.

Second, 65 per cent of workers agreed that 'elected institutions are the best place to pursue worker interests'. This compared with 59 per cent (1994) and 57 per cent (1998) of workers who agreed that 'parliament is the best forum to pursue worker interests'. Although the 2004 question was more broadly phrased than the earlier ones, the responses suggest that workers' faith in the democratic polity is increasing rather than decreasing - although the 26 per cent minority of workers who disagreed with the question in 2004 (9 per cent remaining neutral) was sizeable and stands firmly alongside the 54 per cent who felt that political parties could not be trusted to pursue worker interests. Hence, while workers were giving their broad stamp of approval to democratic institutions, they displayed a strong streak of scepticism about political parties.

Third, when Cosatu workers were asked whether if Cosatu representatives elected (under the aegis of the ANC) to political institutions 'do not do what workers want, they should be recalled or removed from parliament' an overwhelming majority $(87 \%)$ responded in the affirmative. However, the message they gave was ambiguous, for a simply majority $(57 \%)$ of respondents said that such representatives should be recalled through the electoral process (ie, at the next election, despite the fact that voters vote for parties rather than individuals), while only 30 per cent said that such representatives should be recalled 'through mass action'. Nonetheless, despite the ambiguity, the replies would seem to indicate workers' desire for more direct electoral control over individual MPs.

Fourth, the previous finding is given some considerable support by workers' answers to the question whether they would prefer to be represented by members elected to Parliament through a party list, constituency or mixed electoral system. The response was very divided, with 39 per cent supporting the party list system, 34 per cent supporting a constituency based system, 21 per cent supporting a mixed system and just 7 per cent answering 'don't know'. Overall, therefore, 55 per cent of Cosatu workers, who remain at the core of the ANC support base, favoured a change that would introduce constituencies into the electoral system in some form, while 60 per cent explicitly favoured the retention of overall proportionality.

Of course, the above findings are only indicative, but they do meld well with commentary to the effect that ordinary South Africans, whatever their political orientation, want MPs to be more directly accountable to the voters. ${ }^{4}$ This feeling has almost certainly been strengthened by the remarkable changes which have

4 In his column 'Separation of Powers' in The Sunday Independent, Rob Amato ran his own highly unscientific poll on whether his readers wanted to see a reintroduction of constituencies. He received 82 replies, all of which favoured constituencies; four of them explicitly advocating mixed systems. Their motivations were summarised by the submission of Tony Voss who, in arguing for constituencies, wrote his reasons as (i) reputation and accountability (ii) regional variety and local knowledge. But Amato worried that only four of his respondents were identifiably black. 'Readers want their own MPs', Sunday Independent, 22 August 2004. 
taken place in the party political arena following the popular casting of votes in the election of 2004.

The most immediate casualty of the 2004 general election was the New National Party (NNP), which was reduced to just 1,65 per cent of the vote and seven seats. In 1994, the then National Party secured 20,39 per cent of the vote and eighty-two seats and served as the junior partner, under its leader, former President F W de Klerk, in the Government of National Unity (GNU). Subsequently, after the promulgation of the final Constitution in 1996, it had left the GNU for the opposition benches. Following a poor performance in the election of 1999 (6,87 per cent of the vote and 28 seats) under the inexperienced leadership of Marthinus van Schalkwyk, it merged with the then Democratic Party to form the Democratic Alliance (DA), again as the junior partner. However, Van Schalkwyk swiftly found himself uncomfortable with the vigorous opposition pursued by the DA under its leader, Tony Leon. Consequently, he fairly swiftly took his party out of the DA to join up once again with the ruling party in a loose coalition that enabled the ANC and NNP acting together to seize control of the Western Cape and Cape Town City Council as a result of the floor-crossing saga of 2002-03. First in government then out of it, then in alliance with the DP, then out of the DA, then in informal alliance with the ANC once again - this was too dizzying a ride for the majority of the NNP's voters, most of whom shifted to the DA and the new Independent Democrats in the election of 2004. It was therefore scarcely surprising when, after the election, Van Schalkwyk accepted a Cabinet post in the ANC-led government, and subsequently announced that he would be joining the ANC and advising the rest of the members of his party to accompany him. Although constrained from formally crossing the floor of Parliament until the next window opens, Van Schalkwyk has, in essence, pronounced the death of the party of apartheid and the seven NNP MPs have in effect (albeit not yet in law) crossed to the ANC.

The Constitution, as originally promulgated, had prohibited floor crossing, exemplifying the logic that once voters had decided upon the representation of political parties in legislative assemblies through nation list PR, politicians should not have the liberty to change it. However, politicians from diverse backgrounds were soon complaining that this arrangement was too inflexible. This was particularly the case at local government level. At national and provincial levels, although individuals could not change parties, parties could change alliances (thus enabling the NNP to switch its affiliation from the DP to the ANC). However, at local government level, where the NNP and DP had contested the 2000 elections as the DA, NNP councillors were locked into the DA, even though they now wanted to align themselves once more with the ANC. It was in this context that, having already collapsed DA rule at provincial level in the Western Cape, the ANC introduced Bills (for national and provincial assemblies, and for local government separately) that would enable floor crossing, albeit at pre-ordained windows of opportunity, as long as those crossing the floor constituted ten per cent or more of a political party's representation in a given forum. The result was predictable: in 
due course, the ranks of the ANC in Parliament were swelled by the addition of some ten MPs, and at local government level, the DA lost control of half the councils on which it had gained majorities in the 2000 local government elections.

As noted, the NNP's capitulation after the 2004 general election has not yet led to formal floor crossings in Parliament. However, an indication of what is in store has been provided by the most recent bout of floor crossings that have taken place at local government level, where, during a fourteen-day window period, many councillors sought to position themselves better to secure re-election in the local government elections scheduled for 2005. Overall, between 1 and 14 September 2004 some 486 councillors changed political allegiance and 160 of the country's 284 municipalities were affected by floor crossings. Overall, the NNP lost 283 councillors, the overwhelming majority of them crossing to the ANC, which gained 330 new councillors and control of eight municipalities. In contrast, the DA gained 66 councillors, and the Independent Democrats 39 (This Day, 20 September 2004; Mail $\mathcal{E}$ Guardian Online, 21 September 2004).

There can be little doubt that, overall, these shenanigans - the NNP leadership deciding to merge with the ANC without formal reference to its membership just weeks after a general election, and the further mass exodus of councillors from parties for which they had previously presented themselves to the voters - have seriously dented the popular image of politicians. An Afrobarometer survey (cited in the Financial Mail, 24 September 2004) has recorded that fully 63 per cent of voters disapprove of floor crossing and are alienated by what they see as cynical moves by politicians to secure power and financial advantage. 'Out with chequetocracy', calls Motsoko Pheko, president of the Pan Africanist Congress, who refers to floor crossers as 'cheque crossers' because of their acceptance of offers made to them in secret. 'Voters in this country vote for Parties, not cheque-crossers. Floor-crossing encourages corruption and self interest. It violates the electoral right of the voters' (Pheko 2004). Floor-crossers, echoed an editorial in Business Day (2 September 2004), are 'Crosstitutes'.

Meanwhile, the reputation of politicians has plunged further thanks to the socalled 'Travelgate' scandal that rocked Parliament after the elections. This refers to a list of some $136 \mathrm{MPs}$, including four Cabinet ministers, two deputy ministers, two premiers and senior office holders within Parliament, who are being investigated by the anti-corruption unit, the Scorpions, for irregular use of travel vouchers - a scam that, overall, has cost the taxpayer some R17-million. It must be stressed that, at time of writing, no allegations against any MPs have been proved, and that in many cases the corrupt misuse of travel vouchers may have been the responsibility of four Cape Town travel agents rather than that of the MPs themselves (ThisDay, 2 September 2004). None the less, not least because the ANC in particular made a determined bid to prevent the names of the MPs who are being investigated from being published only to be thwarted by the (now defunct) newspaper, ThisDay, which the ANC threatened to sue for defamation!), the affair has severely sullied the reputation of Parliament, and those who belong to it. It can 
only increase the popular sense that politicians are unwilling to render themselves accountable to those who elect them.

Significant commentators are beginning to argue that a re-introduction of constituencies would render legislative representatives more accountable to voters. According to DA leader Tony Leon, only 175 ward (local government constituencies) councillors have crossed the floor during the two local government floor-crossing periods, compared to 388 proportional representation councillors (Sunday Times online, 2 October 2004). Not surprisingly, given that floor crossing has hugely benefited the ANC and extended its already overwhelming dominance, the DA has committed itself to reforming the floor-crossing system as it presently operates, and it is also clear that it favours some re-introduction of constituencies. In this at least, the DA seems to be putting itself at the head of popular opinion, and it is likely to be joined by the other parties of opposition, most of which (notably the UDM and IFP) have suffered badly as a result of floor crossing. Yet this, of course, spells danger - for if the issue of electoral and legislative reform becomes even more crudely politicised along party lines, it is only the ANC that will win.

\section{Electoral Reform and Political Accountability}

Developments since the 2004 election have strengthened the case for electoral reform featuring the introduction of multi-member constituencies, alongside a compensating proportional list system. Such a system of MMP has been successfully introduced in Lesotho, where, in contrast to contemporary South Africa, historic reliance upon a first-past-the-post constituency system produced huge imbalances in Parliament in the elections of 1993 and 1998 and resultant political instability. The addition of a PR list system to the existing constituencies in the 2002 election corrected representative imbalances, and considerably eased political tensions in a country with an unhappy past.

There is no reason, save that of the self-interest of the ANC, why a reverse approach to MMP cannot be engineered in South Africa, whereby the undesirable political consequences of proportionality can be addressed, at least in part, through the sort of mixed system which was proposed by the ETT. All the indications are that, overall, such a change would be favoured by a majority of the electorate, including - if the recent Cosatu worker survey is anything to go by - a majority amongst the ANC's own support base.

The government has promised that the present Parliament will address the issue of electoral reform once more. However, there is, at present, little indication that the ANC will advance from its present strict adherence to the list system PR that has been so advantageous to it. The list system has immensely facilitated centralised control of party structures, and has enabled the party leadership to contain factionalism at provincial and local government levels. Meanwhile, its considerably more cynical espousal of floor crossing has increased its electoral dominance at all three levels of government well beyond the degree voted for by 
the electorate. Significantly, survey results indicate that the electorate disapproves of this manipulation of the popular will and would prefer to see the dominance of party leaderships curbed. This, it must be recalled, appears to be the attitude of all voters, including those who are aligned to the ANC.

Constituencies are favoured because individual voters want to have a direct electoral connection with MPs who they feel know particular geographical areas and have their interests at heart. Voters feel that it is more likely that they can render constituency MPs, who have to take notice of local interests as well as following the instructions of party leaderships, politically accountable. Constituencies, it is felt, will provide MPs with a degree of independence from their party: they will be accountable downwards (to constituents) as well as upwards (to the party leadership). Furthermore, the introduction of constituencies is seen as inhibiting the extent of floor crossing, for floor crossers elected by constituencies will face the wrath of their constituencies at a following election. Finally, a further advantage often adduced for constituencies is that their introduction would allow individuals to stand as independents, which they are unable to do under the present national list PR system. Although it is rare for independent candidates ever to be elected for constituencies in modern political systems, the capacity for independents to rattle cages at local level during election campaigns remains highly valued.

It must be stressed that the introduction of multi-member constituencies alongside a PR list, as the ETT recommended, is a very modest change. It would not affect the size of the ANC majority, and is highly unlikely to impinge seriously on the capacity of party leaderships to impose day-to-day party discipline. It would, certainly, require of political parties that they adjust their candidate selection procedures, and there is nothing to stop them devising procedures whereby candidates who do not subscribe to their principles and behavioural demands can present themselves for selection as constituency candidates. (For instance, individuals seeking election as Labour Party MPs in the United Kingdom first have to gain access to a nationally approved list of potential candidates). It would also mean that, to ensure an appropriate representation of women, the ANC and opposition parties would have to devise suitable procedures for candidate selection at constituency level, while also being prepared to use the national list to ensure adequate gender compensation.

The advantages would be that (i) voters would feel closer to constituency MPs than they do to PR MPs; (ii) constituency MPs would have a constitutional responsibility to represent the views and interests of the their constituents; (iii) the introduction of constituencies would enhance the personal accountability to voters of individual MPs; and (iv) enhanced accountability of constituency MPs might facilitate political communication between ordinary people and the government, while encouraging a capacity for independent thinking and action amongst parliamentary representatives.

Overall, it is argued that the introduction of multi-member constituencies alongside PR, as suggested by the ETT, will increase Parliament's legitimacy. Yet it 
also needs to be stressed that the beneficial effect of any such change is likely to be completely negated unless the blatantly undemocratic effects of the floor-crossing system are also addressed. Floor crossing as it currently operates manifestly works in favour of the ruling party, undermines opposition (and hence the potential for accountability), and runs completely counter to the logic of PR. Importantly, too, it severely detracts from the legitimacy of Parliament and of politics in general by encouraging the view that politicians are far more interested in their own futures than they are in the pursuit of public interest.

There is, of course, an immediate remedy at hand: alongside electoral reform as envisaged by the ETT, legislation could require (i) that floor crossing by MPs elected by PR be prohibited completely; (ii) that constituency MPs who cross the floor should be allowed to remain in Parliament for a given period (long enough for them to raise issues of principle) before being required to submit themselves to re-election in a by-election.

Such changes would require of the ANC in particular that it make certain sacrifices, yet they would in no way seriously threaten its capacity to govern. In contrast, they would confirm a commitment to the virtues of parliamentary democracy for which the party struggled so heroically for so long.

\section{- REFERENCES -}

Amato, R. 2004. 'Wraiths to board planes unnoticed: electoral reform strategy reaches a nadir with Asmal's suppression of part of task team's report'. Sunday Independent, 3 October.

ANC. 2002. 'ANC Submission on a Future Electoral System to the Electoral Task Team': Resolution of the National Policy Conference. 17 October. http:// www.anc.org.za/ancdocs/misc/electsub.html

Fox R and Southall, R. 2003. 'Adapting to Electoral System Change: Voters in Lesotho, 2002'. Journal of African Elections 2(2), pp 86-96.

Matlosa, K. 2003. 'Review of electoral systems and democratisation in Southern Africa'. In Electoral Models for South Africa: Reflections and Options, Electoral Task Team Review Roundtable 9-10 September 2002. Johannesburg: Konrad Adenauer Foundation, pp 47-66.

Mattes, R and Southall, R. 2004. 'Popular Attitudes Toward the South African Electoral System'. Democratization 11(1), pp 51-76.

Morna, C L. 2002. 'Time to enshrine women's political share in law'. Sunday Independent, 10 November.

Pheko, M. 2004. 'Out with chequetocracy'. This Day, 9 September.

Southall, R (ed). 2001. Opposition and Democracy in South Africa. London; Portland, Oregon: Frank Cass.

Southall, R and Mattes, R. 2002. Popular Attitudes Towards the South African Electoral System: Report to the Electoral Task Team. Democracy and Governance Occasional Paper No 1, Human Sciences Research Council. 